\title{
Analysis of Mechanical Properties and Permeability of Sand Moulding by Using Eggshell in Sand Casting
}

\author{
Wahyu Kurnianto ${ }^{1,3}$, Poppy Puspitasari ${ }^{12}$, and Wahono ${ }^{1}$ \\ ${ }^{1}$ Department of Mechanical Engineering, Faculty of Engineering, Universitas Negeri Malang \\ ${ }^{2}$ Center of Nano Research and Advanced Materials, Universitas Negeri Malang \\ ${ }^{3}$ Bachelor Program, Mechanical Engineering Department, Universitas Negeri Malang \\ *poppy@um.ac.id
}

\begin{abstract}
This study aimed to analyse the usage of Eggshell as mixture material of bentonite in metal casting process which used dried sand moulding. Eggshell variations in this study were 4\%, 7\%, 10\% eggshell, and additional $3 \%$ of bentonite on each sample. This study used pre-experimental method and included to OneShot Case Study model. The highest strength was found on the sample 3 ES 10\%. Tensile strength of dried sand moulding reach up to $0.09 \mathrm{~kg} / \mathrm{cm}^{2}$, the compressive strength of dried sand moulding reached up to 3.11 $\mathrm{kg} / \mathrm{cm}^{2}$, and the shear strength of dried sand moulding reached up to $1.13 \mathrm{~kg} / \mathrm{cm}^{2}$. Based on the test result indicated that permeability of sand moulding by heat treatment at $110^{\circ} \mathrm{C}$ for 60 minutes at sample of $3 \mathrm{ES}$
\end{abstract} $10 \%$ was at $178.3 \mathrm{ml} / \mathrm{min}$.

Copyright (C) 2018Journal of Mechanical Engineering Science and Technology

All rights reserved

Keywords: Mechanical properties, permeability, sand moulding, eggshell.

\section{Introduction}

Metal casting is process of formation of work piece that conducted by melting or heating metal, then poured into moulding to form the desired work piece. Nowadays, casting process by using sand moulding is widely used due to its relatively low cost of raw materials, various size and composition, and also it is possible to reuse the sand moulding [1]

Material which commonly used in metal casting is aluminium. Based on the World Economic Outlook, IMF, submitted in October 2015, aluminium was in third ranked as the main base metal, with the value of global sales of USD 90 billion per year (Ministry of Industry of Republic Indonesia, 2016). While the Medias which used in sand casting practice are composed of several compositions, such as silica sand, bentonite, water, carbon, and water-resistant powder.

Generally, the binder used in sand casting is single binder bentonite. Bentonite is used as a binder in manufacture of sand moulding due to its necessary properties that generate high binding capacity, being clay when wet, so it will facilitate the making process of moulding, it's being hard after drying [2].

In this study, the binder material that used in sand moulding was bentonite mixed eggshell. Utilization of eggshell was dominated in cosmetics and fertilizer for the plant due to its high calcium content. The usage eggshell in casting had not been interesting. While the chemical content of eggshell represented $11 \%$ of total weight of the egg and composed of calcium carbonate (94\%), calcium phosphate $(1 \%)$, organic material $(4 \%)$, and magnesium carbonate $(1 \%)$ [3].

Previous study under the title "The Effect of Combined Limestone and Quicklime Addition to K300 Concrete Mixture," the limestone was used as one of binder in this study, the calcium content had superiority as an adhesive, materials with calcium content was selected due to their properties which was able to be hardened after mixed with water [4]. 


\section{Methodology}

This study used pre-experimental research design with one-shot case study model, in which sample group was given a treatment then the results was observed. The independent variable in this study was comparison of silica sand with Eggshell as mixture of sand moulding with the percentage of silica sand $88 \%, 85 \%$ and $82 \%$ and binder Eggshell with a percentage of $4 \%, 7 \%$ and $10 \%$. The dependent variables in this study were the permeability, tensile strength, compressive strength, and shear strength. The control variable in this study was water with percentage of $5 \%$ in all of samples, eggshell with a mesh size of 200 or fineness of $0.02 \mathrm{~mm}$, bentonite with percentage of 3\% and silica sand with a mesh size of 40 or fineness of $0.4 \mathrm{~mm}$.

The composition of sand moulding which were used in this study were divided into several variations, they were:

- $4 \%$ eggshell, $3 \%$ bentonite, $88 \%$ silica sand, and 5\% water (sample 1 ES $4 \%$ ).

- $7 \%$ eggshell, $3 \%$ bentonite, $85 \%$ silica sand, and 5\% water (sample 2 ES 7\%).

- $10 \%$ eggshell, $3 \%$ bentonite, $82 \%$ silica sand, and 5\% water (sample 3 ES 4\%).

\section{Results and discussion}

\section{A. X-Ray Diffraction Analysis}

Before conducting sand moulding test, material which was used as mixed binder in casting process should be tested using XRD test to determine the elements contained in eggshell. The XRD results had been showed in Figure 1 and Table 1.

According to calculation of eggshell crystal based on XRD result, the crystal size of sintered eggshell nanopowder at temperature of $1100^{\circ} \mathrm{C}$ was $59.7912 \mathrm{~nm}$, it was consistent with Hall Petch's law that stated the smaller the crystal size, the harder the material hardness [5], as showed in Table 2.

\section{B. Mechanical Properties Testing}

Mechanical properties testing of sand moulding in this study was divided into two states conditions. They were in wet and dry conditions of sand moulding.

1) Mechanical Properties Analysis of Sand Moulding in Wet Condition.

According to Figure 2, obtained research result which stated that each moulding had the different of strength value. The sand moulding strength in wet conditions increased along with the increasing of bentonite content and showed the optimum value with the particular bentonite content [6]. This showed that the adding of binder in different percentage yielded different strengths. The different percentage of binder mixture in a wet sand moulding caused differences in strength [7]

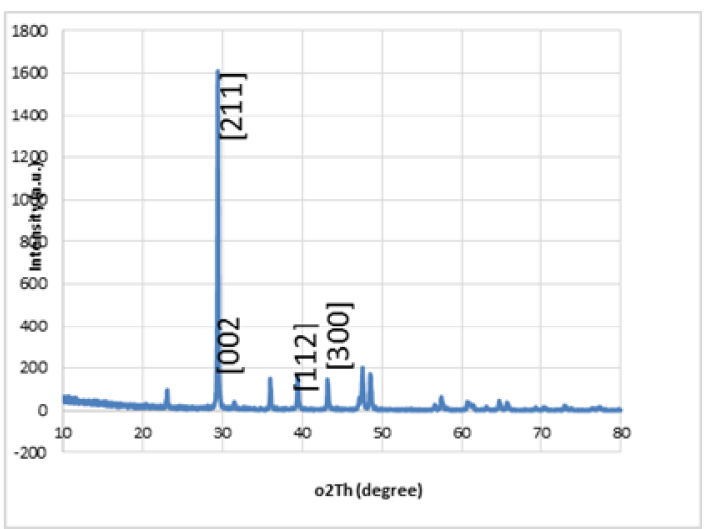

Fig. 1.Phase Identification of Sintered Eggshells Nanopowder treatment at Temperature of $1100^{\circ} \mathrm{C}$

Table 1. Phase Identification of Sintered Eggshells Nanopowder at Temperature of $1100^{\circ} \mathrm{C}$

\begin{tabular}{ccccc}
\hline Post. [ 20] & Height [cts] & FWHM [ 20] & d-spacing [̊] & Rel.Int. [\%] \\
\hline 29.4265 & 1606.40 & .1378 & 3.03541 & 100.00 \\
\hline
\end{tabular}

Wahyu Kurnianto et.al (Analysis of Mechanical Properties and Permeability of Sand Moulding) 
The highest mechanical properties which consisted of tensile strength, compressive strength and shear strength of sand moulding in wet conditions was sampling 3 ES 10\%. The highest tensile strength of sand moulding was $0.068 \mathrm{~kg} / \mathrm{cm}^{2}$, this showed that this sand moulding in wet condition was worth to be used due to its value included into standard value, that was 0.07 to $0.42 \mathrm{~kg} / \mathrm{cm}^{2}$, the highest compressive strength was $0.74 \mathrm{~kg} / \mathrm{cm}^{2}$, in this case the compressive strength of sand moulding was also worth to be used due to its value was included into standard value, that was 0.35 to $1.54 \mathrm{~kg} / \mathrm{cm}^{2}$. While, the highest shear strength was $0.28 \mathrm{~kg} / \mathrm{cm}^{2}$ also was included into standard value that was 0.10 to $0.49 \mathrm{~kg} / \mathrm{cm}^{2}$. Compared to the previous study, the result of this study showed the better result. The previous study (Muzayyin, 2017) used sand moulding that consisted of $85 \%$ silica sand, $10 \%$ bentonite and $5 \%$ water and yielded tensile strength was $0.06 \mathrm{~kg} / \mathrm{cm}^{2}$, compressive strength was $0.54 \mathrm{~kg} / \mathrm{cm}^{2}$, and shear strength was $0.022 \mathrm{~kg} / \mathrm{cm}^{2}$. Based on the explanation, the mixture of $10 \%$ eggshell and 3\% bentonite could be used as binder in casting to reduce the usage of bentonite.

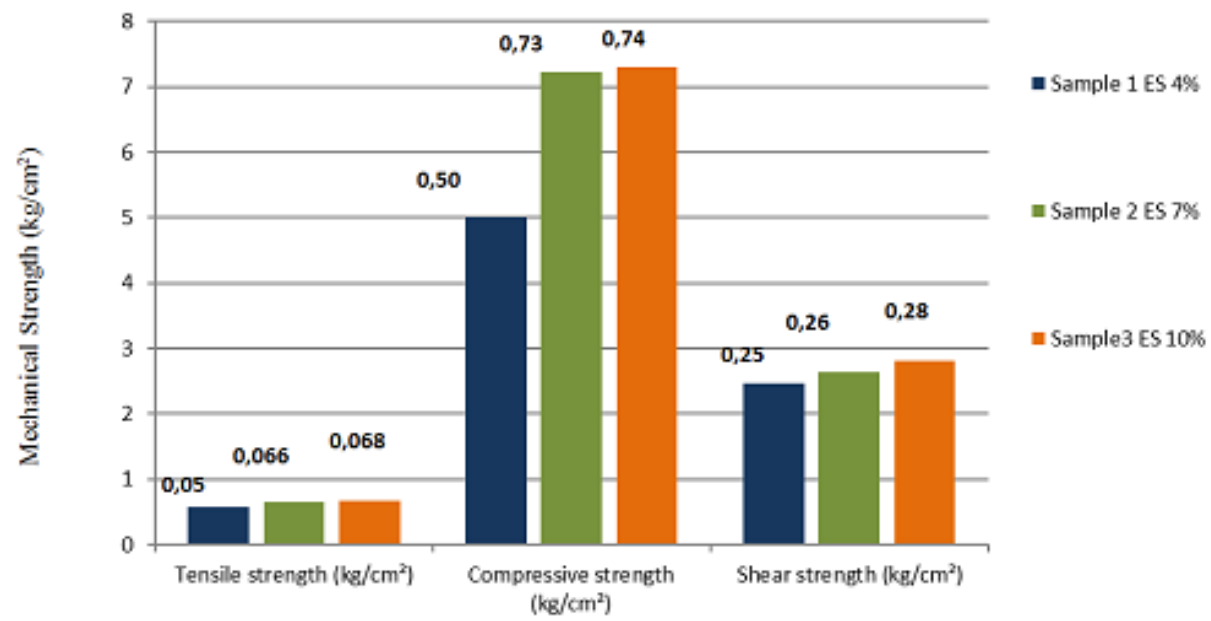

Fig. 2.Bar Chart Mechanical Properties Analysis of Sand Moulding in Wet Condition

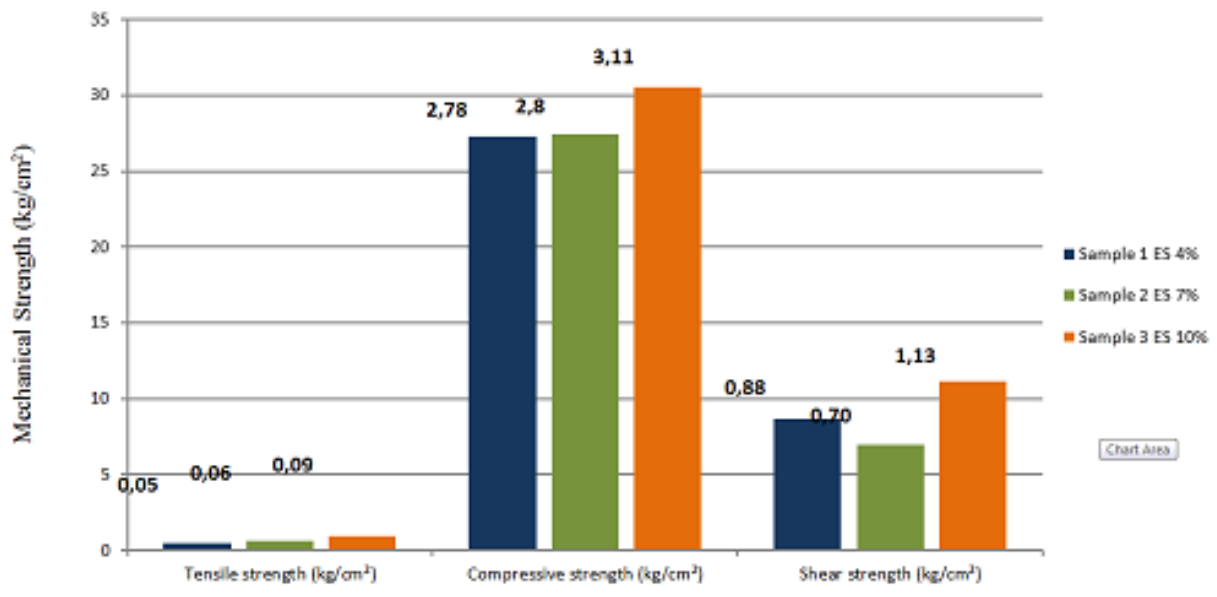

Fig. 3.Bar Chart Mechanical Properties Analysis of Sand Mouldibg in Dry Condition 
2) Mechanical Properties Analysis of Sand Moulding in Dry Condition.

According to Figure 3 could be understood that sand moulding which had the highest mechanical properties in dry condition was sample 3 ES $10 \%$. This sample had the highest tensile strength of $0.09 \mathrm{~kg} / \mathrm{cm}^{2}$, this value included into standard value of sand moulding that was 0.07 to $0.42 \mathrm{~kg} / \mathrm{cm}^{2}$. While the highest value of compressive strength was $3.1 \mathrm{~kg} / \mathrm{cm}^{2}$ and this value included into standard value that was 1.5 to $17.5 \mathrm{~kg} / \mathrm{cm}^{2}$, The addition of limestone $\left(\mathrm{CaCO}_{3}\right)$ into Lapindo mud affected the compressive strength of concrete which made of Lapindo mud [8]. The higher calcium that used would yield a high compressive strength, and the highest shear strength of $1.13 \mathrm{~kg} / \mathrm{cm}^{2}$, but this shear strength value was not included into standard, that was 0.10 to $0.49 \mathrm{~kg} / \mathrm{cm}^{2}$. This result consistent with the result entitled Analysis of Binding Material Variation in Sand Moulding Malang Against The Strength and Permeability with composition of $10 \%$ bentonite, $82 \%$ sand, $8 \%$ water had tensile strength value of $0.07 \mathrm{~kg} / \mathrm{cm}^{2}$, compressive strength of $1.2 \mathrm{~kg} / \mathrm{cm}^{2}$, and shear strength of $0.5 \mathrm{~kg} / \mathrm{cm}^{2}$ [9], [10]. Sand moulding with a natural binder was able to obtain better mechanical properties at the casting of aluminium alloy [11].

\section{Permeability Testing}

Permeability test was a test which conducted to determine the ability of sand moulding to be able to transport gas/air and water vapour which contained in sand moulding. Casting defects occurred due to the condition was not optimal during the casting process [12]. Therefore, needed space between the sand grains for place where gas escaped during casting process. The amount of air/gas through the sand moulding should be indicated on the permeability meter [13]. Permeability value should not be low or high, usually the value was ranged between 50-170 $\mathrm{ml} / \mathrm{min}$. All samples used $5 \%$ of the water which was the optimum value for binding.

Low permeability of sand moulding caused the air difficulty in flowing through the sand grain [2]. As the result when the molten metal poured, the air/gas couldn't flow properly and caused defects on the casting product. Conversely, if the permeability was too high, the cast metal could sink in between the sand grain and the result was the rough surface on the casting.

According to explanation above, the content of binder in moulding composition was excessive would create a gap between the sand grain tightly, thus making the air got difficulty in flow. While the content of binder in moulding was less would create a gap between the sand grain loosely so air flowing easily. Related to this study, the lack of binder in sample 1 ES $4 \%$ would make the gap between the grain getting loose so that the air easily flowed and while the binder content in sample 3 ES $10 \%$ was excess that made a gap between the sand grain getting narrower so the air got difficulty in flowing. The sample 2 ES 7\% had the highest value for the percentage of binder content. Sample $1 \mathrm{ES} 4 \%$ and sample $3 \mathrm{ES} 10 \%$ with the percentage of sand was $85 \%$. The result of this study was better compared with the other study entitled Analysis Binder Material Variations in Sand Moulding Malang against Strength and Permeability with composition of $10 \%$ starch, $82 \%$ sand, $8 \%$ water with the permeability value of $180 \mathrm{ml} / \mathrm{min}$.

THE RESULT OF SAND MOULDING PERMEABILITY

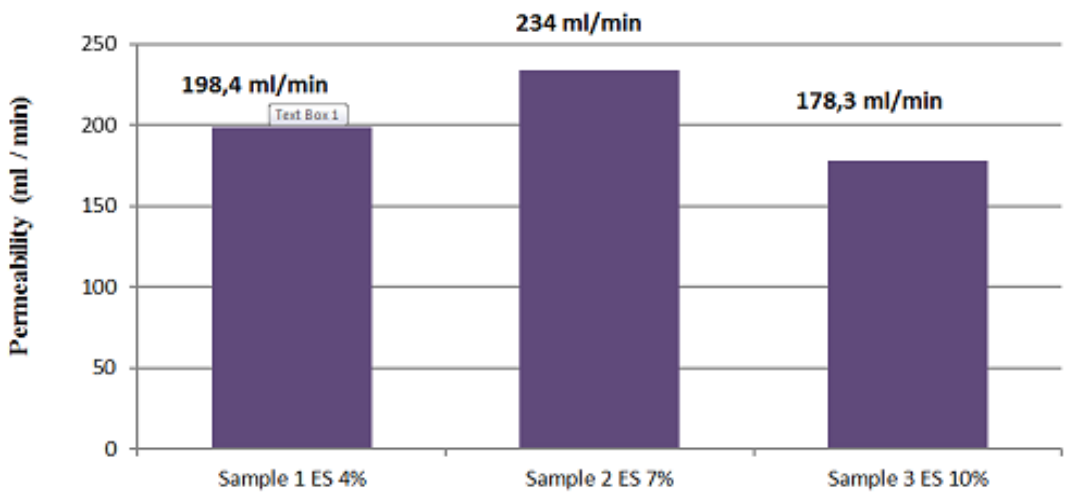

Fig. 4.Bar Chart Sand Moulding Permeability 
Combination of $5 \%$ bentonite and $5 \%$ of portland cement generated permeability up to 176 $\mathrm{ml} / \mathrm{min}$ [2]. Previous study entitled Analysis of Variations in composition of Fly Ash and Bentonite as Binder of Sand Moulding against Permeability, Compressive Strength and fluidity of Green Sand Moulding with the composition of $7 \%$ bentonite and $2 \%$ fly ash, this molten had permeability of $231.67 \mathrm{ml} / \mathrm{min}$.

As the highlight, mechanical properties value of sample 3 ES $10 \%$ on sand moulding in dry condition had the highest value and the permeability of sample 3 ES $10 \%$ had the lowest score. But, the value was slightly higher than the standard that had been determined ie. $50-170 \mathrm{ml} / \mathrm{min}$.

According to study result, the recommended composition for casting process was sampling 3 ES $10 \%$ in dry conditions. Sand moulding in dry conditions was more improved the mechanical strength due to water which absorbed on the surface of sand grain had been removed. Sand with binder of dried clay had the best permeability and strength which increased compared to the wet one, as water was absorbed on the surface of clay grain had been removed. Besides having a high value on mechanical properties, the sample 3 ES $10 \%$ had permeability value that approached standard that had been determined in casting, thus the samples 3 ES 10\% was suitable for the composition of sand moulding in casting.

\section{Conclusion}

Based on the discussions that had been presented, could be concluded that sand moulding in dry condition with a proper permeability value which was suitable for use in metal casting according to standard was the composition of sample 3 ES $10 \%$ with permeability value of $178.3 \mathrm{ml} / \mathrm{min}$. The highest tensile strength value and included into standard that was in sample 3 ES $10 \%$ with tensile strength value of $0.09 \mathrm{~kg} / \mathrm{cm}^{2}$, compressive strength of $3.11 \mathrm{~kg} / \mathrm{cm}^{2}$, and shear strength of 1.13 $\mathrm{kg} / \mathrm{cm}^{2}$.

\section{References}

[1] C. Saikaew dan S. Wiengwiset, "Applied Clay Science Optimization of molding sand composition for quality improvement of iron castings," Appl. Clay Sci., vol. 67-68, hal. 26-31, 2012.

[2] Andoko, P. Puspitasari, A. A. Permanasari, dan D. Z. Lubis1, "Formula of Moulding Sand, Bentonite and Portland Cement toImprove The Quality of Al-Si Cast Alloy," J. Mech. Eng. Sci. Technol., vol. 1, no. 2, hal. 49-52, 2017.

[3] F. S. Murakami, P. O. Rodrigues, C. Maria, T. De Campos, M. Antônio, dan S. Silva, "Physicochemical study of CaCO 3 from egg shells," vol. 27, no. 3, hal. 658-662, 2007.

[4] J. J. Darren, D. Gunaran, H. Hendy, dan E. K. Budirahardjo, "Pengaruh Penambahan Gabungan Batu Kapur the Effect dan Batu Kapur Padam pada Campuran Beton K-300," hal. 141-148.

[5] M. Multigner, E. Frutos, J. L. González-Carrasco, J. A. Jiménez, P. Marín, dan J. Ibáñez, "Influence of the sandblasting on the subsurface microstructure of $316 \mathrm{LVM}$ stainless steel: Implications on the magnetic and mechanical properties," Mater. Sci. Eng. C, vol. 29, no. 4, hal. 1357-1360, 2009.

[6] W. Yu, H. He, N. Cheng, B. Gan, dan X. Li, "Preparation and experiments for a novel kind of foundry core binder made from modified potato starch," Mater. Des., vol. 30, no. 1, hal. 210-213, 2009.

[7] N. T. Herwido, P. Murdanto, dan P. Puspitasari, "Analisis Variasi Komposisi Fly Ash Dan Bentonit Pada,” J. Mech. Eng. Sci. Technol., no. 1, hal. 1-11, 2016.

[8] A. Pujianto, A. NA, M. DC, dan Hendra, "Kuat Tekan Beton Geopolimer dengan Bahan Utama bubuk Lumpur lapindo dan Kapur," Konf. Nas. Tek. Sipil, vol. 7, no. KoNTekS 7, hal. 129-136, 2013.

[9] Anon, "Sand/binders/sand preparation/mold \&amp; coremaking," Foundry Manag. Technol., vol. 124, no. $1,1996$.

[10] M. Holtzer, "The Mold/Casting Interface Phenomena," in Microstructure and Properties of Ductile Iron and Compacted Graphite Iron Castings: The Effects of Mold Sand/Metal Interface Phenomena, 2015, hal. $77-108$.

[11]W. A. Ayoola, S. O. Adeosun, O. S. Sanni, dan A. Oyetunji, "Effect of casting mould on mechanical properties of 6063 aluminum alloy," J. Eng. Sci. Technol., vol. 7, no. 1, hal. 89-96, 2012.

[12] M. V. Mohiuddin, A. Krishnaiah, dan S. F. Hussainy, "Effect of Composition of Sand Mold on Mechanical Properties and Density of Al-Alloy Casting Using Taguchi Design Approach,” Int. J. Eng. Res. Appl., vol. 5, no. 3, hal. 37-41, 2015. 
[13] S. Priyadharsini dan P. Karunakaran, "Determination of the Physical Properties of Sand Moulding Bonded with Composite of Ipomoea Batatas and Bentonite with Casting Application," hal. 2913-2919, 2016. 